\title{
THE IMPLEMENTATION OF PHYSICAL EDUCATION, SPORT AND HEALTH LEARNING THROUGH SPORTS GAME IN BUILDING PRIMARY STUDENTS' CHARACTERS
}

\author{
Pajar Anugrah Prasetio ${ }^{1}$, Yuniarti ${ }^{2}$, Febby Fajar Nugraha $^{3}$ \\ ${ }^{1}$ Education Program of Elemantary School of Universitas Kuningan \\ ${ }^{2}$ Education Program of Elemantary School of Universitas Kuningan \\ ${ }^{3}$ Education Program of Elemantary School of Universitas Kuningan \\ ${ }^{1}$ pajar.anugrah@uniku.ac.id, ${ }^{2}$ yuniarti@uniku.ac.id, ${ }^{3}$ febbyfajar@uniku.ac.id
}

\begin{abstract}
This research aimed to investigate the implementation of physical education, sport, and health learning through sports game in building primary students' characters. The method employed in this research is qualitative descriptive. The subjects of this research were five graders and physical education teachers at SDN 1 Awirarangan, SDN 2 Awirarangan, SDN 1 Karangtawang, and SDN 2 Karangtawang, Kuningan, West Java. The data was taken interactively and continuously. The main instruments of this research were observation, interview, and documentations. The data were analyzed in accordance with the frameworks proposed by Miles and Huberman which were data collection, data reduction, data presentation, drawing conclusion and verification. The result showed that learning physical education through sports game is a media that can be used to build students' characters. Through sports game, someone could gain self-control and work together very well. Values like responsible, honest, brave, cooperative, confident, tolerant, mutual respect, religious, polite, wisely accept victory and defeat could be gained through the implementation of a sports game. To sum up, the implementation of physical education through sports game is an alternative media to build primary students' characters.
\end{abstract}

Keywords: Physical education, Sports game, Character education

\begin{abstract}
Abstrak
Penelitian ini bertujuan untuk menyelidiki implementasi pendidikan jasmani, olahraga, dan pembelajaran kesehatan melalui permainan olahraga dalam membangun karakter siswa sekolah dasar. Metode yang digunakan dalam penelitian ini adalah deskriptif kualitatif. Subjek penelitian ini adalah lima siswa kelas dan guru pendidikan jasmani di SDN 1 Awirarangan, SDN 2 Awirarangan, SDN 1 Karangtawang, dan SDN 2 Karangtawang, Kuningan, Jawa Barat. Data diambil secara interaktif dan terus menerus. Instrumen utama penelitian ini adalah observasi, wawancara, dan dokumentasi. Data dianalisis sesuai dengan kerangka kerja yang diusulkan oleh Miles dan Huberman yaitu pengumpulan data, reduksi data, penyajian data, penarikan kesimpulan dan verifikasi. Hasil penelitian menunjukkan bahwa belajar pendidikan jasmani melalui permainan olahraga adalah media yang dapat digunakan untuk membangun karakter siswa. Melalui permainan olahraga, seseorang bisa mendapatkan kontrol diri dan bekerja sama dengan sangat baik. Nilai-nilai seperti bertanggung jawab, jujur, berani, kooperatif, percaya diri, toleran, saling menghormati, religius, sopan, dengan bijak menerima kemenangan dan kekalahan bisa didapat melalui penerapan permainan olahraga. Singkatnya, penerapan pendidikan jasmani melalui permainan olahraga adalah media alternatif untuk membangun karakter siswa sekolah dasar.
\end{abstract}

Kata Kunci: pendidikan jasmani, permainan olahraga, pendidikan karakter

\section{INTRODUCTION}

Lately, characters education started to gain serious attention from Indonesia government. Efforts have been done by the government to build the national characters. One of its realizations is by holding events in which the activities could help the government in 
shaping, developing, and attuning Indonesian citizen with national characters. Issues related to the importance of characters education started after mass media posted articles about the degradation of young generation's moral and ethics. Moral crisis in the society could be identified by the followings: 1) untrustworthy; 2) irresponsibility; 3) not visionary; 4) indiscipline; 5) uncooperative; 6) injustice; and 7) indifference (Ginanjar, 2008).

Characters education is needed to overcome the problem related to Indonesian cultural values that start to decrease. This condition is quite worrying as it could lead to weakening national character. The term character comes from the Latin word "Charasein" which means carving out the permanent pattern. According to the big Indonesian dictionary, character means psychological traits, morals or qualities that distinguish an individual with others (Balai Pustaka, 1995, p. 445). Character is a concept from moral which is composed of a number of characteristics that can be mold through sports activities, such as compassion, fairness, sportsmanship, and integrity (Weinberg \& Gould, 2002).

Ateng (1983) explained that physical education is the integration of education as a whole through several physical activities which aimed to organically, neuromuscular, intellectually and emotionally develop an individual. Specifically, it can be said that physical education is an effort to attain educational goals through physical activity. Physical education and sport at school become an important medium to develop and improve human resources. It also has function as a mean (1) to channel emotion, (2) to strengthen identity, (3) as social control, (4) to socialize, (5) an agent of change, (6) to express inner voice, and (7) to achieve success (Wuest \& Bucher, 1995).

Therefore, based on the previously mentioned issues, this research was intended to investigate how is physical education, sport, and health learning being implemented through sports game in developing primary school students' characters.

\section{METHOD}

This current research employed a qualitative descriptive method which further being interpreted as describing and presenting research data in words. Moleong (2012, p. 6) explained that qualitative research is research that aimed to explore and describe the phenomenon experienced by the research subject, in an authentic specific context with several natural methods. The description is used to find out principals and explanations which lead to a conclusion. The particular concern in this current research is the implementation of physical education, sport, and health learning through sports game in developing primary school students' characters. The following is a chart on steps in conducting this research: 


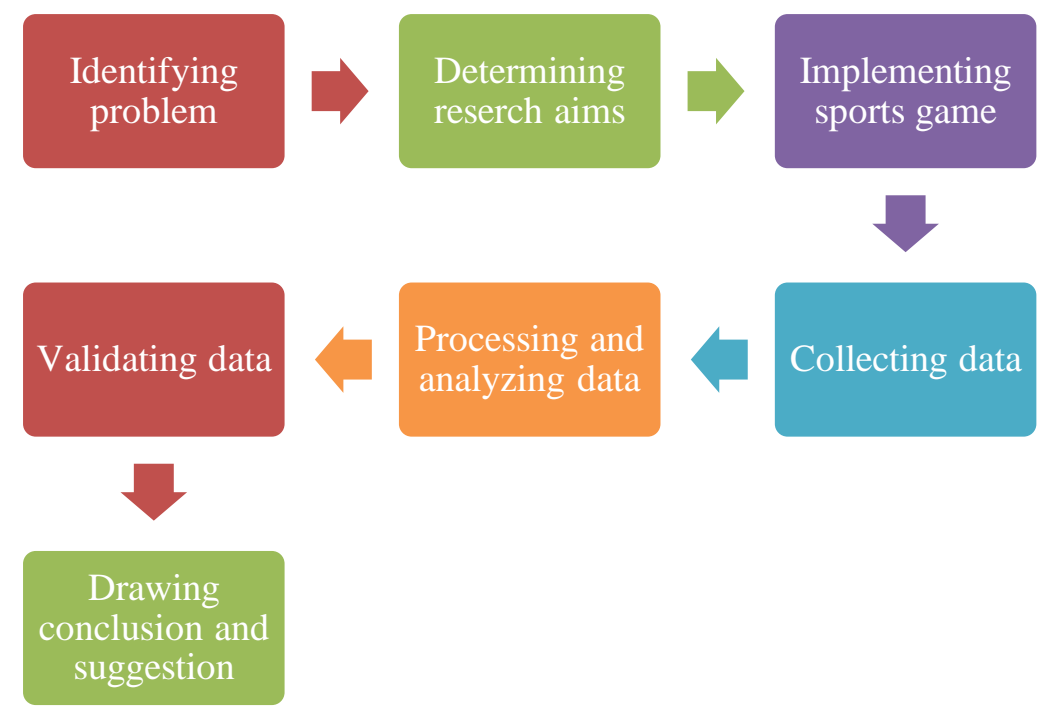

Figure 1. Research design

The subjects of this research were students and physical education (PE) teachers from several government primary schools around Kuningan district, such as: SDN 1 Awirarangan, SDN 3 Awirarangan, SDN 1 Karangtawang dan SDN 2 Karangtawang. This research was conducted in four months, from July to October 2018. It started with initial observation until directing PE teachers in implementing sports game activities in their classes in accordance with the physical education curriculum for primary school.

\section{RESULTS AND DISCUSSION}

Learning is a process of reciprocal interaction in which knowledge and experiences are being transferred from teachers to learners. Although the teacher's role is not very dominant, it is still very important for the knowledge transfer in the learning process runs well. To maximize the role of the teacher in the learning activity, it is essential to plan a lesson which followed by its implementation, assessment, and evaluation.

Learning physical education, sport and health through sports game become a media that can be used as a tool to develop human's characters. Sport with its slogan "sport for all" is the first strategic step toward the development of characters. Through sports game, characters building could be based on national culture and also enriched by culture and special characteristics of every sport that is being played. Positive characters could be gained and developed by learning physical education, sport, and health. Through sport, an individual may have self-control and a good sense of cooperation. Values like diligent, honesty and bravery are also grown from sports activities. 
Physical education, sport, and health learning through sports game is a learning material that could help the teacher in building student's characters. It is because, in a sports game, students' good character like responsible, honest, brave, cooperative, confident, tolerant, mutual respect, religious, polite and many more could be developed. The example of implementing character in learning physical education are beginning the lesson with prayer, being polite toward teachers, discipline and not late in attending the class, tolerant toward others, being wisely able to accept defeat and victory. These facts became to prove that physical education, sport, and health subject could not be ignored. Through the implementation of a sports game, positive characters like having self-control and cooperative were well developed as it expected.

Based on the data taken from SDN 1 Awirarangan, SDN 3 Awirarangan, SDN 1 Karangtawang and SDN 2 Karangtawang, it was known that the implementation of physical education, sport, and health learning through sports game is an alternative media and technique that could develop primary school students' characters. How the PE class being conducted could be seen from the lesson plan made by PE teachers and its implementation.

The implementation stage of PE learning through sports games at SDN 1 Awirarangan, SDN 3 Awirarangan, SDN 1 Karangtawang and SDN 2 Karangtawang was focused on learning experience and the process of learning that centered on shaping students' characters. The teachers that were chosen to be the subject of this research possessed good characteristics, such as: honest, responsible, innovative, implementing their role as a teacher to give a good example, motivator, inspiratory, evaluator and dynamist for their students. Teachers could give good examples as an effort in shaping students' character. Students will imitate what they saw and heard from a teacher, therefore, PE teacher should have good characters. PE teacher could give encouragement to the students for always improving oneself. While implementing the sports game, PE teachers appreciated the students in the form of praises for those who did it right and punishment for those who made mistakes. Teachers' praises could motivate the students and encourage them to improve their self-quality. Meanwhile, the students who made mistakes were given punishment to provide a deterrent effect. PE teachers also inspired students by speaking politely, well-mannered and responsible.

Suharjana (2011, p. 35) said that physical education and sport as a subject which could improve an individual's self-control and cooperative. Through physical education and sport, someone might channel his/her anger because sport could relax tense muscles including muscles and nerves that are used to vent emotions. In sport, self-control was taught by the 
teacher through mental exercises. This could be gained from the competition where the audiences or opponent often throw mockery and ridicule to get the player angry. Therefore, PE and sport are important to develop someones or students characters and self-control in a competition.

It previously mentioned that physical education and sport could build cooperation. Through physical education, sport and health, students were being taught on how to be part of a team and maintain good cooperation that could help to win the game. Good cooperation in a team leads to winning. Then, by developing self-control at an early age, students will gain benefits for their physical growth, emotional expression and knowledge to support their future.

\section{CONCLUSION}

1. Based on the research, it can be concluded that physical education, sport, and health learning through sports game is an alternative media that can be used as a tool to build students' characters. Through this learning, positive characters were formed as a result of doing sports. Through sports, an individual could have good self-control and cooperative. Furthermore, values like responsible, honest, brave, confidence, tolerant, mutual respect, religious, polite, wisely accept victory and defeat also could be gained from a sports game.

2. Based on the entire research that has been done at SDN 1 Awirarangan, SDN 3 Awirarangan, SDN 1 Karangtawang and SDN 2 Karangtawang, it was known that the implementation of physical education, sport, and health learning through sports game is an alternative media that can be used as a tool to build students' characters. The implementation could be seen from the planning that has been made by the teachers in their lesson plan. This also represented on how they carried out the lesson. On the implementation stage at every school, the teacher focused their lesson on learning experiences and shaping students' characters through the sports game. The teachers that were chosen to be the subject of this research possessed good characteristics, such as: honest, responsible, innovative, implementing their role as a teacher to give a good example, motivator, inspiratory, evaluator and dynamist for their students. The students have often received encouragement from the teachers in the form of praises for those who did it right and punishment for those who made mistakes. Teachers' praises could motivate the students and encourage them to improve their self-quality. 


\section{REFERENCES}

Ginanjar, A. (2008). Rahasia sukses membangun kecerdasan emosional dan spiritual. Jakarta: Arga.

Kemendiknas. (2010). Bahan pelatihan penguatan meteodologi pembelajaran berdasarkan nilai-nilai budaya untuk membentuk daya saing dan karakter bangsa pengembangan pendidikan budaya dan karakter. Jakarta: Kemendiknas.

Moleong, J.L. (2012). Metodologi penelitian kualitatif. Bandung: PT. Remaja Rosda Karya.

Suharjana. (2011). Pengembangan pembelajaran senam melalui bermain di sekolah dasar. Jurnal Pendidikan Jasmani Indonesia. 9 (1) : 35.

Weinberg, R. (2002). Foundations of sport \& exercise psychology. United States : Human Kenetic.

Wuest, D.A. \& Bucher. (1995). Foundations of psycal education and sport. St. Louis Missouri : Mosby-Year Book. 